\title{
Pengaruh Kepercayaan Diri terhadap Kemandirian Anak di Taman Kanak-Kanak
}

\author{
Rusmayadi \\ Pendidikan Guru Anak Usia Dini Universitas Negeri Makasar \\ Email: Rasmayadi@gmail.co.id
}

\begin{abstract}
ABSTRAK
Penelitian ini bertujuan untuk mengetahui pengaruh kepercayaan diri terhadap kemandirian anak-anak di kelas penitipan anak. Penelitian ini menggunakan metode survei dengan pendekatan kuantitatif. Penelitian survei yang dimaksud adalah menggambarkan hubungan sebab akibat yang biasa disebut analisis jalur. Sampel ditentukan secara acak, yaitu TK Lotus, TK Rahmah, dan TK Aisyiah Perumnas II dengan sampel 142 siswa. Analisis jalur mensyaratkan bahwa data yang akan dianalisis memenuhi beberapa uji statistik, yaitu: (1) Uji normalitas, (2) Uji Homogenitas, (3) Uji Signifikansi dan Uji Linearitas dari Koefisien Regresi dan (4) Uji Multicolourity. Dalam penelitian ini ditemukan bahwa ada hubungan yang signifikan antara Keyakinan (X1) dan Independensi (X2). Kedekatan hubungan antara X1 dan X2 dikonfirmasi oleh hasil pengujian hipotesis bahwa ada efek langsung positif SelfConfidence (X1) pada Independence (X2). Hasil pengujian hipotesis menunjukkan bahwa Kepercayaan Diri (X1) memiliki pengaruh signifikan terhadap Independensi (X2) sebagaimana dibuktikan oleh hasil uji statistik. Ukuran kontribusi variabel Keyakinan Diri terhadap Kemandirian secara statistik ditunjukkan oleh nilai $(\rho y 1 \times \rho y 1)=0,32 \times 0,32=0,10$ atau $10 \%$. Nilai ini menunjukkan bahwa sekitar 10\% variasi dalam kemandirian anak-anak di taman kanak-kanak (Grup B) dijelaskan secara langsung oleh kepercayaan diri.
\end{abstract}

Kata Kunci: Kepercayaan; Anak usia dini; Kemerdekaan

\begin{abstract}
This study aims to determine the effect of self-confidence in children's independence in the nursery. This study uses a survey method with a quantitative approach. The survey research in question is describing a causal relationship commonly referred to as path analysis. The samples were randomly determined, namely Lotus Kindergarten, Rahmah Kindergarten, and Kindergarten Aisyiah Perumnas II with a sample of 142 students. Path analysis requires that the data to be analyzed meet several statistical tests, namely: (1) Normality test, (2) Homogeneity Test, (3) Test of Significance and Linearity Test of Regression Coefficient and (4) Multicolourity Test. In this study it was found that there was a significant relationship between Confidence (X1) and Independence (X2). The closeness of the relationship between $X 1$ and $X 2$ is confirmed by the results of testing the hypothesis that there is a positive direct effect of Self-Confidence (X1) on Independence (X2). The results of hypothesis testing indicate that Self Confidence (X1) has a significant effect on Independence (X2) as evidenced by the results of statistical tests. The size of the contribution of the Self Confidence variable to Independence is statistically indicated by the value $(\rho y 1 \times \rho y 1)=0.32 \times 0.32=0.10$ or $10 \%$. This value indicates that approximately $10 \%$ of the variation in the independence of children in kindergarten (Group B) is explained directly by self-confidence.
\end{abstract}

Keywords: Confidence; Early Childhood; Independence.

(C) 2019 Rasmayadi Under The License CC-BY-SA 4.0 


\section{PENDAHULUAN}

Pendidikan anak usia dini merupakan wahana pendidikan yang sangat fundamental dalam memberikan kerangka dasar terbentuk dan berkembangnya dasardasar pengetahuan, sikap dan keterampilan pada anak. Karena usia dini merupakan periode awal yang paling penting dan mendasar sepanjang rentang pertumbuhan dan perkembangan kehidupan manusia. Ini merupakan salah satu periode yang sangat penting, karena periode ini merupakan tahap perkembangan kritis. Periode ini kemudian disebut dengan periode emas (golden age). Salah satu sikap dan perilaku yang ditanamkan melalui lingkungan sekolah adalah kemandirian. Kemandirian anak merupakan anak yang mampu memenuhi kebutuhannya baik berupa kebutuhan naluri maupun kebutuhan fisik, oleh dirinya sendiri secara bertanggunjawab tanpa bergantung pada orang lain.

Kemandirian anak juga dapat diartikan sebagai keterampilan untuk membantu diri sendiri baik kemandirian secara fisik maupun kemandirian secara psikoligis. Kemandirian secara fisik merupakan kemampuan untuk mengurus diri sendiri dan kemandirian secara psikologis merupakan kemampuan untuk membuat keputusan dan memecahkan masalah yang dihadapi. Stein dan Book menyatakan bahwa kemandirian merupakan kemampuan untuk mengarahkan dan mengendalikan diri sendiri dalam berpikir dan bertindak, serta tidak merasa bergantung pada orang lain secara emosional. Anak yang mandiri adalah anak yang memiliki kepercayaan diri dan motivasi yang tinggi. Sehingga dalam setiap tingkah lakunya tidak banyak menggantungkan diri pada orang lain, biasanya pada orang tuanya.

Anak yang kurang mandiri selalu ingin ditemani atau ditunggui oleh orang tuanya, baik pada saat sekolah maupun pada saat bermain. Kemana-mana harus ditemani orang tua atau saudaranya. Berbeda dengan anak yang memiliki kemandiran, ia berani memutuskan pilihannya sendiri, tingkat kepercayaan dirinya lebih nampak, dan mudah menyesuaikan diri dengan lingkungan dan teman bermain maupun orang asing yang baru dikenalnya.

Luther memberikan peninjauan dari perspektif psikologis bahwa kemandirian pada dasarnya berawal dari adanya rasa kemandirian diri (self-efficacy) atau persepsi seseorang tentang seberapa baik individu dapat menangani suatu masalah yang muncul. Setiap anak itu cenderung untuk mandiri atau memiliki potensi untuk mandiri, karena setiap anak dikarunia perasaan, pikiran, kehendak sendiri, yang kesemuanya itu merupakan totalitas psikis dan sifat-sifat serta struktur yang berlainan pada tiap-tiap fase perkembangannya. 
Hal. 27- 33

Menurut Bathi, kemandirian merupakan perilaku yang aktivitasnya diarahkan kepada diri sendiri, tidak banyak mengharapkan bantuan dari orang lain, dan bahkan mencoba memecahkan masalahnya sendiri. Dengan kepercayaan dirinya, anak berani tampil dan berekspresi di depan orang banyak atau di depan umum. Penampilannya tidak terlihat malu-malu, kaku, atau canggung,tapi ia mampu beraksi dengan wajar dan bahkan mengesankan. Anak yang memiliki motivasi tinggi ini dapat terlihat dari perilakunya yang aktif, kreatif, dan memiliki sifat ingin tahu (curiositas) yang tinggi. Anak tersebut biasanya selalu banyak bertanya dan serba ingin tahu, selalu mencobanya, mempraktekkannya, dan mencoba-coba sesuatu yang baru.

\section{Kemandirian}

merupakan kemampuan penting dalam hidup seseorang yang perlu dilatih sejak dini. Seseorang dikatakan mandiri jika dalam menjalani kehidupan tidak tergantung kepada orang lain khususnya dalam melakukan kegiatan sehari-hari. Kemandirian juga ditunjukkan dengan adanya kemampuan mengambil keputusan serta mengatasi masalah. Dengan demikian setiap anak perlu dilatih untuk mengembangkan kemandirian sesuai kapasitas dan tahapan perkembangannya. Kemandirian anak sangat erat kaitannya dengan anak sebagai individu yang mempunyai kepercayaan diri yang berdampak pada kemampuan anak memahami tuntutan lingkungan terhadap dirinya dan menyesuaikan tingkah lakunya.

Kepercayaan diri merupakan aspek kepribadian yang penting untuk dikembangkan pada anak usia dini. Aspek ini memberikan pengaruh yang cukup besar dalam kemandirian anak dalam rangka penanaman perilaku kedisiplinan. Sebagian anak memiliki rasa percaya diri dan hal ini sangat tergantung kemampuan yang dimiliki dirinya. Kurang percaya diri pada anak akan menghambat pengembangan potensi kemandirian.

(Valentine, Dubois, \& Cooper) menuliskan Both self-esteem and self confidence (and also self efficacy) share a common emphasis on the individual's beliefs about his or her attributes and abilities as a person, and various measures of self-esteem and self-confidencelefficacy have been found to correlate with each other highly. (Valentine, Dubois, \& Cooper menuliskan keduanya, harga diri dan kepercayaan diri (dan juga efikasi diri) secara umum memberikan penekanan pada keyakinan individu tentang identitasnya dan kemampuan diri sendiri, dan berbagai ukuran harga diri dan kepercayaan diri/khasiat telah ditemukan sangat berkorelasi satu dengan yang lain.

David menyatakan bahwa rasa percaya diri adalah bagian sangat penting 
dari kepribadian seseorang. Gambaran percaya diri tampak melalui konsistensi dari ketekunan seseorang dalam menghayati peranannya. Kepercayan diri merupakan milik pribadi yang sangat penting dan ikut menentukan kebahagiaan hidup seseorang. Seseorang yang tidak memiliki kepercayaan diri akan tumbuh menjadi individu yang tidak kreatif dan tidak produktif. Kepercayaan diri dimanifestasikan dalam sikap positif seorang individu yang memampukan dirinya untuk mengembangkan penilain positif baik terhadap diri sendiri maupun terhadap lingkungan sekitar.

John W. Santrock menegaskan Kepercayaan diri adalah keyakinan dalam diri seseorang akan kemampuannya, kelayakannya untuk meraih kesuksesan. Kepercayaan diri erat hubungannya dengan kepribadian seseorang untuk dapat beradaptasi dengan lingkungannya. Personality refers to distinctive thoughts, emotions, and behaviors that characterize the way an individual adapts to the world. (Kepribadian mengacu pada pengalaman khas, emosi, dan perilaku yang menjadi ciri cara individu beradaptasi dengan dunia).

\section{METODE PENELITIAN}

Penelitian ini menggunakan metode survei dengan pendekatan kuantiatif. Penelitian survei yang dimaksud adalah bersifat menjelaskan hubungan kausal yang biasa disebut dengan path analysis (analisis jalur). Penelitian analisis jalur adalah suatu teknik untuk mengestimasi pengaruh seperangkat variabel independen (eksogen) terhadap variabel dependen (endogen) dalam hubungan sebab akibat. Ada beberapa asumsi yang harus dipenuhi dalam penelitian path analysis yaitu: (1) hubungan antar variabel adalah bersifat linier. (2) Sistem aliran kausal satu arah artinya tidak ada arah kausalitas yang berbalik. (3) Variabel endogen berskala interval atau rasio. (4) menggunakan sample probability. (5) Variabel yang diteliti dapat diobservasi. (6) Model yang dianalisis diidentifikasi secara benar berdasarkan teori yang relevan atau dibangun berdasarkan kerangka teoritis yang mampu menjelaskan hubungan kausalitas antarvariabel. Variabel terdiri dari kepercayaan diri anak $\left(\mathrm{X}_{1}\right)$, dan kemandirian anak $\left(\mathrm{X}_{2}\right)$. Teknik analisis data yang digunakan terhadap data penelitian ini meliputi: teknik analisis deskriptif, analisis uji persyaratan, dan analisis inferensial.

\section{HASIL DAN PEMBAHASAN}

Data yang diolah dalam penelitian ini diperoleh dari sampel penelitian yang berjumlah 142 responden anak usia dini yang merupakan anak didik taman kanakkanak Kota Makassar semester genap tahun pelajaran 2015/2016. Pengambilan sampel dilakukan dengan teknik multistage random cluster sampling. Data dihitung dan 
dianalisis secara deskriptif untuk empirik skor terendah adalah 48 dan mengetahui rerata (mean), median, modus, tertinggi adalah 66, dengan nilai skor standar deviasi, varian, skor maksimum, skor minimum, rentang (range), dan jumlah rentang sebesar 18. Adapun nilai rata-rata kepercayaan diri sebesar 56,37; median skor. 56,00 dan modus 52. Standar deviasi atau

Berdasarkan data yang diperoleh di lapangan, secara teoretik skor untuk variabel ini terbentang dari 21 hingga 85. Secara empirik, skor terendah dan tertinggi berawal dari 48 dan berakhir pada 66, artinya secara simpangan baku skor kepercayaan diri sebesar 3,735. Distribusi frekuensi skor variabel kepercayaan diri yang sudah dikelompokkan dapat dilihat pada tabel 1 . berikut:

Tabel 1. Distribusi Skor Kepercayaan Diri (X)

\begin{tabular}{cccc}
\hline Kelas Interval & Frekuensi Absolut & Frekuensi Kumulatif & Frekuensi Relatif \\
\hline $48-49$ & 2 & 2 & 1,4 \\
$50-51$ & 10 & 12 & 7,0 \\
$52-53$ & 26 & 38 & 18,3 \\
$54-55$ & 22 & 60 & 15,5 \\
$56-57$ & 27 & 87 & 19,0 \\
$58-59$ & 23 & 110 & 16,2 \\
$60-61$ & 19 & 129 & 13,4 \\
$62-63$ & 9 & 138 & 6,3 \\
$64-65$ & 3 & 141 & 2,1 \\
$66-67$ & 1 & 142 & 0,7 \\
Jumlah & $\mathbf{1 4 2}$ & & $\mathbf{1 0 0 \%}$ \\
\hline
\end{tabular}

Berdasarkan tabel 1 di atas dapat dilihat bahwa skor kepercayaan diri yang memiliki frekuensi paling banyak yaitu 27 atau 19,0\% berada pada kelas interval 56-57.
Penyebaran (distribusi) skor untuk variabel skor kepercayaan diri ini secara visual dapat dilihat pada gambar 1 . berikut:

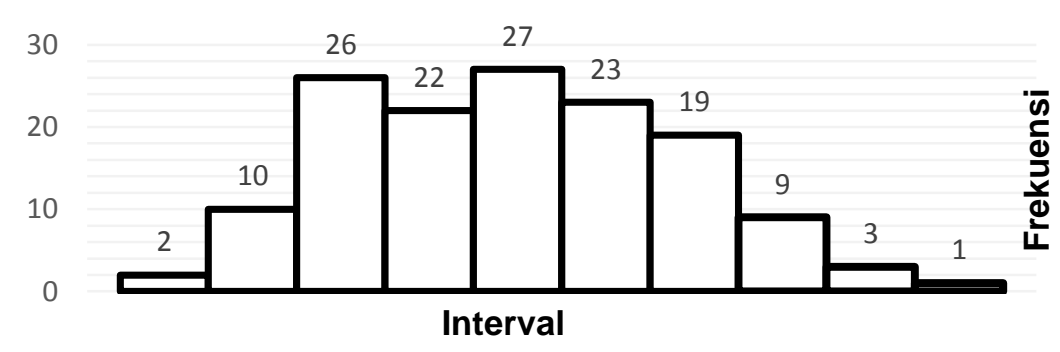

Gambar 1. Diagram Skor Kepercayaan Diri ( $\left.\mathbf{X}_{3}\right)$ 
Hal. 27- 33

Berdasarkan data yang diperoleh di lapangan, secara teoretik skor untuk variabel ini terbentang dari 25 hingga 100. Secara empirik, skor terendah dan tertinggi berawal dari 62 dan berakhir pada 82, artinya secara empirik skor terendah adalah 62 dan tertinggi adalah 82, dengan nilai skor rentang sebesar 20. Adapun nilai rata-rata kepercayaan diri sebesar 73,61; median 74,00 dan modus 72. Standar deviasi atau simpangan baku skor kemandirian sebesar 4,124. Distribusi frekuensi skor variabel kemandirian yang sudah dikelompokkan dapat dilihat pada tabel 2. berikut:

Tabel 2. Distribusi Skor Kemandirian $\left(\mathbf{X}_{2}\right)$

\begin{tabular}{lccc}
\hline Kelas Interval & Frekuensi Absolut & Frekuensi Kumulatif & Frekuensi Relatif \\
\hline $62-64$ & 3 & 3 & 2,1 \\
$65-67$ & 6 & 9 & 4,2 \\
$68-70$ & 21 & 30 & 14,8 \\
$71-73$ & 40 & 70 & 28,2 \\
$74-76$ & 33 & 103 & 23,2 \\
$77-79$ & 29 & 132 & 20,4 \\
$80-82$ & 10 & 142 & 7,0 \\
Jumlah & $\mathbf{1 4 2}$ & & $\mathbf{1 0 0 \%}$ \\
\hline
\end{tabular}

Berdasarkan tabel 2 di atas dapat dilihat bahwa skor kemandirian yang memiliki frekuensi paling banyak yaitu 40 atau 28,2\% berada pada kelas interval 71-73.
Penyebaran (distribusi) skor untuk variabel skor kemandirian ini secara visual dapat dilihat pada gambar 2. berikut:

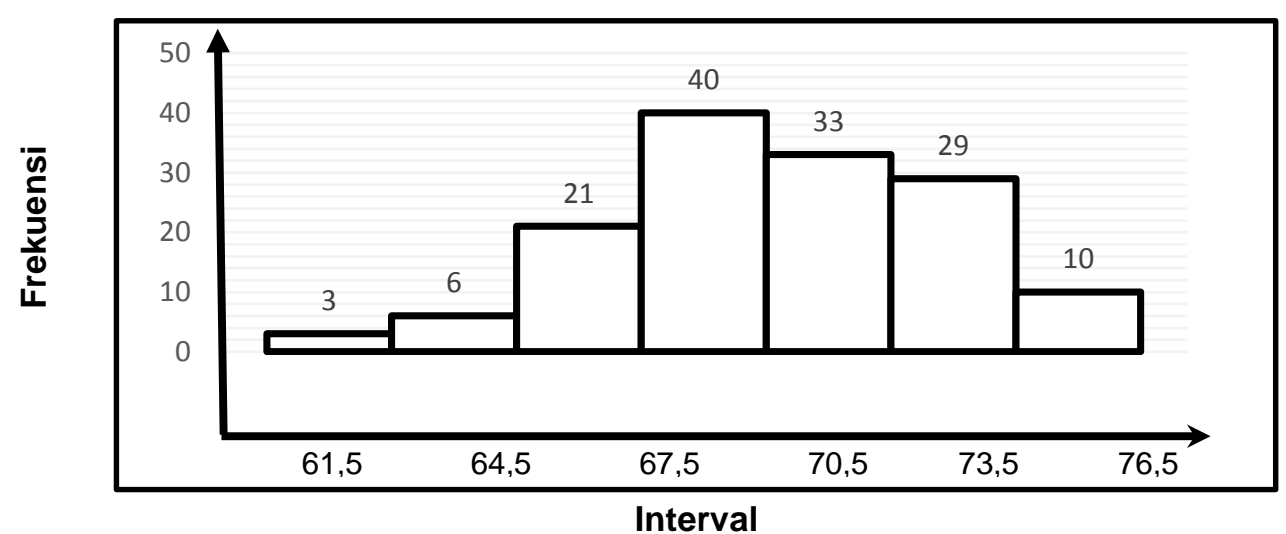

Gambar 2. Diagram Skor Kemandirian $\left(\mathrm{X}_{2}\right)$ 
Hasil analisis data menyimpulkan bahwa harga koefisien jalur $\left(\rho_{21}\right)=0,32$. Harga $t_{\text {hitung }}=3,36$. Angka ini lebih besar untuk $(\alpha=0,05)=1,96$. Fakta ini mengungkapkan bahwa $t_{\text {hitung }}=3,36>t_{\text {tabel }}=$ 1,960 yang berarti $\mathrm{H}_{0}$ ditolak dan $\mathrm{H}_{1}$ diterima. Artinya, koefisien jalur ini signifikan. Temuan dapat ditafsirkan bahwa Kepercayaan Diri $\left(\mathrm{X}_{1}\right)$ berpengaruh langsung positif terhadap Kemandirian $\left(\mathrm{X}_{2}\right)$. Dengan kata lain, Kepercayaan Diri dapat menyebabkan meningkatnya Kemandirian anak taman kanak-kanak. Dalam penelitian ini ditemukan terdapat hubungan yang signifikan antara Kepercayaan $\operatorname{Diri}\left(\mathrm{X}_{1}\right)$ dengan Kemandirian $\left(\mathrm{X}_{2}\right)$. Keeratan hubungan antara $X_{1}$ dan $X_{2}$ dipertegas dengan hasil pengujian hipotesis yakni terdapat pengaruh langsung positif Kepercayaan Diri $\left(\mathrm{X}_{1}\right)$ terhadap $\operatorname{Kemandirian}\left(\mathrm{X}_{2}\right)$.

Hasil pengujian hipotesis menunjukkan bahwa Kepercayaan Diri $\left(\mathrm{X}_{1}\right)$ berpengaruh signifikan terhadap $\operatorname{Kemandirian}\left(\mathrm{X}_{2}\right)$ yang dibuktikan dengan hasil uji statistik. Besarnya kontribusi variabel Kepercayaan Diri terhadap Kemandirian secara statistik ditunjukkan dengan nilai $\left(\rho_{\mathrm{y} 1} \times \rho_{\mathrm{y} 1}\right)=0,32 \times 0,32=0,10$ atau $10 \%$. Nilai ini menunjukkan bahwa kurang lebih $10 \%$ variasi perubahan Kemandirian pada anak taman kanak-kanak dijelaskan secara langsung oleh Kepercayaan Diri.

\section{KESIMPULAN}

Untuk mengembangkan sikap kemandirian anak maka yang perlu diperhatikan adalah kepercayaan dirinya. Sehingga dapat disimpulkan bahwa kepercayaan diri mempunyai pengaruh terhadap kemandirian anak. Semakin percaya diri anak maka semakin banyak kegiatan yang dapat dilakukan secara mandiri.

\section{REFERENSI}

Bathi H.K, 1977, Educational Psyichology (New Delhi: The Macmillen company or India limited)

David G. Mayers. 1983, Social Psychology, (Newyork. Mcgraw-Hill Bool Company.)

Fred Luther, 1995, Organizational Behavior (New York: Mc. Grow-Hill International Edition,)

John W. Santrock, 2008, Educational Psychology, (New York: McGrawHill Companies,)

Steven J. Stein and Howard E. Book, 2000, Ledakan EQ, Terjemahan Trinanda Rainy Januarsari dan Yudhi Murtanto, Bandung: Kaifa

Zoltan Dornyei, 2005, the Psychology of the language Learne: Individual Differences in Second language Acquistion, (New Jersey: Lawrence Associates, Inc,) 